\title{
Biomonitoring of Four Contrasting Wetlands of Kolkata, West Bengal Based on Zooplankton Ecodynamics and Biotic Indices
}

\author{
Poulomi Sanyal $^{1}$, Nandan Bhattacharya ${ }^{2}$, Susanta Kumar Chakraborty ${ }^{1}$ \\ ${ }^{1}$ Department of Zoology, Vidyasagar University, West Midnapore, India \\ ${ }^{2}$ Academic Staff College, Jadavpur University, Salt Lake Campus, Kolkata, India \\ Email: joanofark007@yahoo.co.in
}

Received 15 May 2015; accepted 17 July 2015; published 23 July 2015

Copyright (C) 2015 by authors and Scientific Research Publishing Inc.

This work is licensed under the Creative Commons Attribution International License (CC BY). http://creativecommons.org/licenses/by/4.0/

cc) (i) Open Access

\begin{abstract}
East Kolkata Wetland (EKW) has been assigned the status of Ramsar Site because of its vastness as well as self purification capabilities which have been utilized by local people for the massive agricultural and aquaculture production for more than one century. In this context, an attempt has been made in the present paper to evaluate the existing environmental health of four selected contrasting wetlands of this eco-zone of global importance by qualitative and quantitative hydrobiological studies. Two of the selected wetlands (study site-III and study site-IV) used to receive water from raw sewage after undergoing phytoremediation process. The study site-II has been selected with a view to evaluate the pollution stress on the structural components of this wetland ecosystem as it receives waste water because of anthropogenic activities, and the study site-I is away from any pollution impact as it is located in a well managed natural park. Quantification of the variabilities of different biotic components caused by water pollution has been assessed by recording binary distribution patterns of zooplankton and similarity indices. Besides, new Biotic Indices (Species Pollution Value-SPV and Community Pollution Value-CPV) have been developed using data on the distributional patterns of zooplankton in order to assess the degree of pollution of the studied wetlands. Seasonal water quality data along with qualitative and quantitative information of biological parameters have also been taken into consideration to highlight the impact of phytoremediation on wetland ecosystem dynamics on one hand and pollution stress on the structural and functional components of the water body on the other hand.
\end{abstract}

\section{Keywords}

Wetlands, Ramsar Site, Hydrobiology, Zooplankton, Phytoremediation, Species Pollution Value

How to cite this paper: Sanyal, P., Bhattacharya, N. and Chakraborty, S.K. (2015) Biomonitoring of Four ContrastingWetlands of Kolkata, West BengalBased on Zooplankton Ecodynamicsand Biotic Indices. Journal of Environmental Protection, 6, 683-699. http://dx.doi.org/10.4236/jep.2015.67062 


\section{(SPV), Community Pollution Value (CPV)}

\section{Introduction}

Environmental monitoring of aquatic system is meant for programmed measurement and recording of various water quality parameters in accordance with definite objectives. It includes mostly the estimation of physicochemical parameters of water. Monitoring by evaluating the responses of living organisms (bioindicator species) and their constituent components (biomarkers) represents biomonitoring [1] [2]. "Biomonitoring” (monitoring by biological methods) is an ecological exercise where various kinds of biota (bioindicators) are being used in ascertaining the extent of pollution of a water body [3]-[5].

Wetlands are among the most productive life support systems in the world and are of immense socio-economic and ecological importance to mankind. They play tremendous role in the flood control, improvement of water quality, recycling of natural ground water, acting as buffer against natural disaster, controlling of erosion, sediment's trapping, maintenance of biodiversity, waste water treatment and nutrients' recycling [6]. Within a wetland, the environmental characteristics are determined mostly by hydrological processes which display diurunal, seasonal and even annual fluctuations in response to meteorological, socioeconomic and locational factors [7].

Physicochemical monitoring is a direct method of qualitative and quantitative estimation of physical as well as chemical parameters. Environmental disturbances lead to changes in the structure and the function of biological system from molecular to community level [8]. Moreover, animal and plant community respond to intermittent pollution which physicochemical systems may not identify. Biological assessment for water quality involves three sequential steps-survey, surveillance and monitoring. The first step is for the selection of suitable study site for biomonitoring studies based on topography and socioeconomic condition [9]. Surveillance representing the second step gives emphasis on collection of environmental data both qualitative and quantitative based on which the monitoring programmes determine the status of pollution of the concerned aquatic habitat [10].

However, biomonitoring often causes a lot of confusion on activities relating to its application and consequent results [11] as different environmental managers stress upon different objectives. During last couple of decades, ecologists have been trying to quantify the variation of environmental changes by water pollution. In the earlier studies on biomonitoring of aquatic habitats, aquatic biota and different biotic indices have been considered [12]-[14]. The present paper has attempted to test and verify the applicability of a biotic index developed for biomonitoring based on the qualitative distribution of major aquatic fauna like zooplankton in relation to pronounced ecological parameters of four contrasting wetlands located in and around the East Kolkata Wetland-a Ramsar site.

\section{Materials and Methods}

\subsection{Physiography of Kolkata Wetlands}

Kolkata is sustained by a unique and friendly water regime which is in totality is named as East Kolkata Wet-

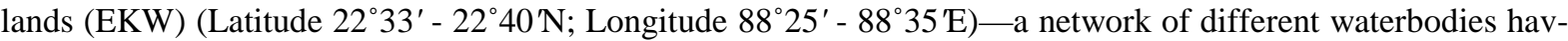
ing different ecological characteristics [15]. To its west, flows the river Hooghly, along the levee of which the city has grown. About $30 \mathrm{Km}$. Eastward, flows the river Kulti-Bidyadhari that carries the drainage to the Bay of Bengal. Underneath the city lies a copious reserve of groundwater. Finally, the central to this regime is the vast wetland area beyond the eastern edge of the city that has been transformed to use city wastewater in fisheries, vegetable gardens and paddy fields in successive tracts of land.

\subsection{East Kolkata Wetland-A Unique Model for Waste Recycling}

East Kolkata Wetland is being considered as a unique model for natural wastewater recycling and has been declared as Ramsar Site in the year 2005 [16]. The eastern bank of the river Hooghly is fringed by a system of low lands and wetlands. The river side on west of the Kolkata is still the highest part of the city, sloping gradually 
away from the river towards the east, the original and natural backyard of the city. The entire drainage and sewage networks of entire Kolkata depends heavily on those natural networks of low lying waterlogged areas, ponds, bheries, ditches, nullahs and tidal creeks connecting with estuarine networks of Hooghly Matla estuarine complex of Sunderban Mangrove Ecosystems. The uniqueness of these wetland networks are for its water recycling system and in the development of sewage fed fisheries on 2500 ha of low lying land supplying 20 tones of fishes daily and employing about thousands of people [17] [18].

The smallest recycling sub region on the edge of the city covers the vegetable fields that grow vegetables on the garbage and are uniquely planned with alternate bands of garbage filled lands and elongated trench - like ponds, locally known as "jheels". In these jheels, sewage is detained for some time, after which the treated effluent is used for irrigating the garbage fields for growing vegetables. In the fishponds, the city's wastewater is made to flow through a network of drainage channels. The wastewater fishponds act as solar reactors and complete most of their biochemical reactions with the help of solar energy [19]. Reduction of Biochemical Oxygen Demand (BOD) takes place due to the unique phenomenon of algae-bacteria symbiosis where energy is drawn from algal photosynthesis. In this way, requirement and consumption of energy have tended to remain at the minimum. Unlike conventional mechanical sewage treatment plants, wastewater ponds can ensure efficient removal of coliforms that are prone to be pathogenic [17].

\subsection{Selection of Study Sites}

For present research investigation, four (4) study sites (S-I, S-II, S-III and S-IV) have been selected along a considerable stretch of the Kolkata Metropolitan based on contrasting ecological characteristics. Study site-I is a managed water body located in the Central park, Banabitan, Salt lake (a site developed for ecotourism). Study site-II (unmanaged wetland, located at Chhappan Talao, Uttar Panchanna Gram, behind Land mark Hotel, by the side of Eastern Metropolitan Bypass - a major roadway of Kolkata) is ecologically stressed water bodies receiving effluents as municipal sewage, detergent wastes out of the activities of washer-men and wastes from automobile cleaning activities of nearby regions. Study site-III (within Nature Park) being a stocking pond sewage receiving sewage water, is being phytoremediated and tended to become an ecorestored water body. Study site IV (also in the Nature Park) is an eco-restored aquatic system receiving water from the stocking pond where sewage water underwent phytoremediation with macrophytes (Figure 1).

\subsection{Seasons and Climate}

Three distinct seasons prevail during the study period each with its own climatic characteristics. The pre-monsoon season includes four months (March - June) and is characterized by highest atmospheric temperature and least precipitation; the monsoon (July - October) experiences highest rainfall, modest air temperature coupled with humidity and in the post-monsoon season (November - February) air temperature comes down to lowest level and receives occasional precipitation.

\subsection{Collection of Water Samples}

Water samples were collected once in a month during early morning at a depth of $0.5 \mathrm{~m}$ from the surface from four (4) different study sites during three consecutive years (July, 2008 - June, 2011) and were kept in 2 liters plastic containers for qualitative and quantitative analysis of different water quality parameters. The bottles were placed in ice-box immediately after samplings.

\subsection{Sampling and Analysis}

\subsubsection{Analysis of Physicochemical Parameters of Water}

Different physicochemical parameters of water (viz. temperature, $\mathrm{pH}$, turbidity, TDS, alkalinity, calcium, magnesium, chloride, total hardness, conductivity, $\mathrm{DO}, \mathrm{BOD}, \mathrm{COD}, \mathrm{Pb}, \mathrm{Cr}, \mathrm{Cd}$ and $\mathrm{Hg}$ ) were estimated by standard methods as outlined by APHA [20]. Water quality assessment was done on the basis of average values of physicochemical components during the study period (July, 2008 - June, 2011).

\subsubsection{Qualitative and Quantitative Estimation of Zooplankton}

The density of zooplankton was quantified on collection of water samples from limnetic zone with the help of 


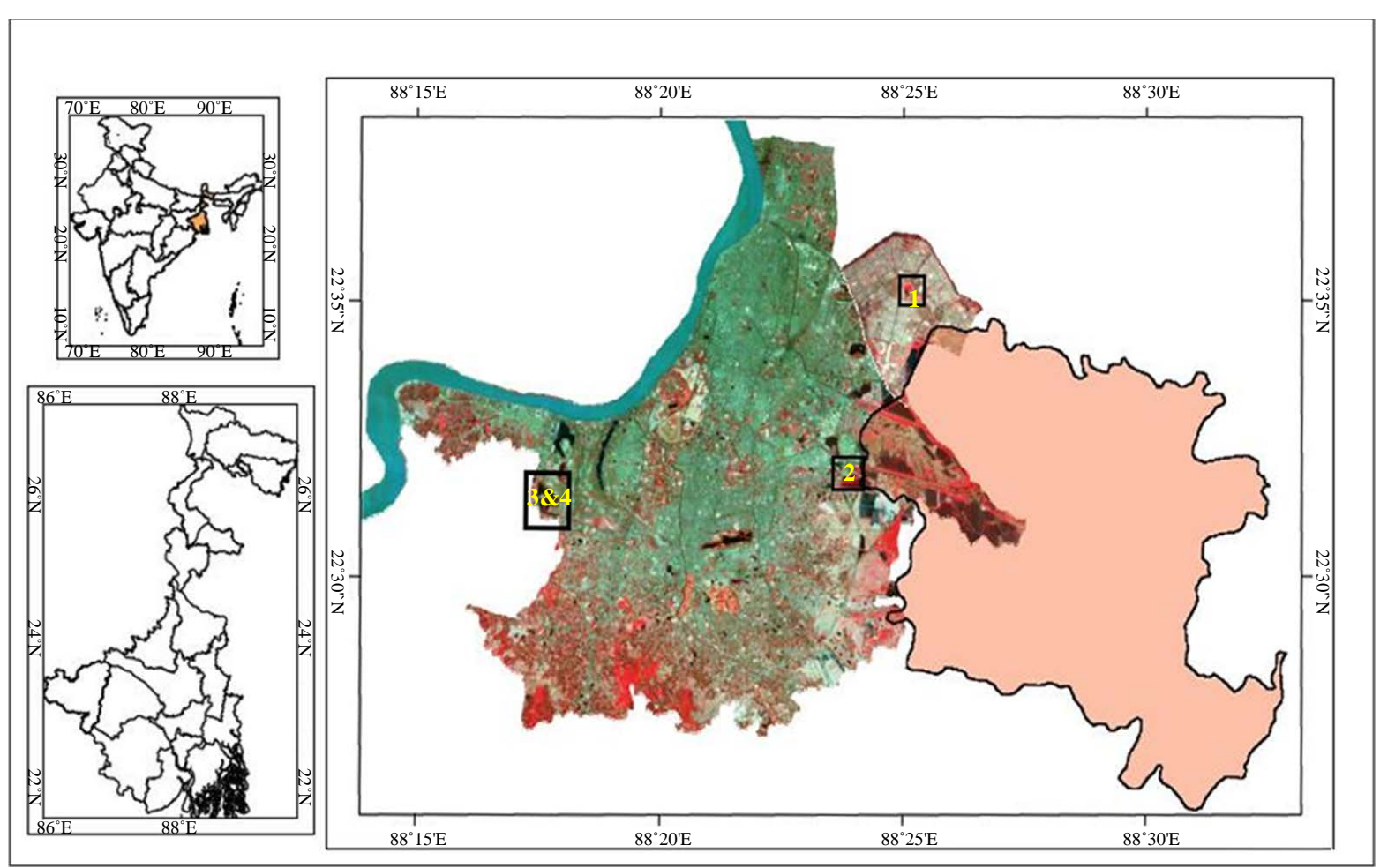

Figure 1. Location map of the study sites. 1 -> S-I [Managed wetland]—located Central Park, Banabitan, Salt Lake, 2 -> S-II [Sewage fed but Unmanaged wetland] - located located at Chhappan Talao, Uttar Panchanna Gram, behind Landmark Hotel (EM - Bypass), 3 -> S-III [Sewage fed but Unmanaged wetland]-located at Nature Park, Taratala, Brace Bridge Wetland and 4 -> S-IV [Fish Cultured and ecorestored wetland]—-located at Nature Park, Taratala, Brace Bridge Wetland.

Plankton Net [of Nylon material with 54 micron mesh size] in which $10 \times 10$ litres of water samples were filtered. Zooplankton were preserved with 4\% buffered formalin [21] [22]. Zooplankton identification was done by some systematic keys [23]-[25]. The density of the zooplankton (rotifera, cladocera and copepoda) was determined under Phase Contrast Microscope (Model No. Carl Zeiss, Germany) and the values were expressed in no./l [26] [27]. Number of zooplankton present in the unit volume of water has been counted with the help of Sedgwick Rafter Counting Chamber [23] [28].

\subsubsection{Calculation of Different Biotic Indices}

Species Pollution Value (SPV) of different species and Community Pollution Value (CPV) of four study sites were calculated following the method suggested by Jiang and Shen, 2003 [29] [30].

Deduction of Species Pollution Value (SPV):

Step I: Calculation of $\mathrm{Pi}$ (Chemical pollution index) (Equation (1))

$$
\mathrm{Pi}=\mathrm{Cd} / \mathrm{Co}
$$

Step II: Calculation of $\mathrm{Pb}$ (Comprehensive chemical pollution index) (Equation (2))

$$
P b=\sum_{i=1}^{n} P i
$$

where $P b$ is the comprehensive chemical pollution index, $P i$ is the chemical pollution index for a single chemical parameter, $C d$ is the concentration of the measured chemical parameter at study site; $C o$ is the upper limit of the concentration of the chemical parameter, $n$ is the number of contributing (chemical) parameters (here $n=9$ ). According to the abovementioned equation, each study site's $P b$ was calculated. In case of dissolved oxygen (DO), Pi was calculated as $\mathrm{Co} / \mathrm{Cd}$ because oxygen decreases in response to pollution.

Step III: Calculation of SPV (Species Pollution Value) (Equation (3)) 


$$
S P V=\frac{\sum_{i=1}^{n}\left(\ln ^{10 P b} / n\right)_{i}}{N}
$$

where $S P V$ is the species pollution value; $P b$ is the comprehensive pollution value; $n$ is the number of contributing (chemical) parameters (here $n=9$ ); and $N$ is the number of study sites.

The Community Pollution Value ( $C P V)$ is used to evaluate the pollution degree of each study sites.

\section{Deduction of Community Pollution Value (CPV) (Equation (4))}

$$
C P V=\frac{\sum_{i=1}^{n} S P V_{i}}{n}
$$

where $C P V$ is the community pollution value; $S P V$ is the species pollution value and $n$ is the number of species in a community.

Calculation of Similarity Index

In addition, study sites were compared using the index of similarity based on the occurrence and distribution of biotic components (zooplankton) [31]. The index of similarity(S)—Equation (5) provides a measure of resemblance of species composition between sampling sites [32].

Calculation of Similarity Index (S) (Equation (5))

$$
S=2 C /(A+B)
$$

where $S=$ index of similarity; $A$ = number of species at study site one; $B=$ number of species at study site another one; $C=$ number of species common to both study sites. Results range from 0 (entirely dissimilar species composition) to 1.0 (identical species composition).

\subsection{Statistical Analysis}

Experimental results were subjected to statistical analysis (Pearson's correlation coefficient and ANOVA). The statistical analysis was carried out using the standard and software package (Microsoft Office XP, excel) and SPSS (version 21.0).

\section{Results}

\subsection{Seasonal Dynamics of Physicochemical Parameters of Water}

Temperature showed clear seasonal trend with maximum temperature during pre-monsoon followed by monsoon at all study sites. Turbidity was recorded maximum during monsoon both at study site-I and study site-IV, while it exhibited highest value (29.1 NTU) during monsoon'09 and lowest value (11.2 NTU) during pre-monsoon'09 at study site-III. It displayed highest and lowest values during monsoon'09 (26.1 NTU) and pre-monsoon'11 (12.7 NTU) at study site-II whereas, the study site-IV showed highest value (9.6 NTU) during monsoon'09 and lowest value during pre-monsoon'09 (5.3 NTU). Highest and lowest values of pH tended to remain more or less same in all four study sites. TDS showed distinct seasonal trend with the maximum value during monsoon at study site-III followed by study site-II, study site-IV and study site-I. The highest value of alkalinity was estimated during pre-monsoon'10 (489.1 mg/l) at study site-III followed by study site-II $(329.7 \mathrm{mg} / \mathrm{l}$ at monsoon’09), study site-IV (235.8 mg/l at pre - monsoon’10) and study site - I (135.9 mg/l at pre-monsoon’09). Total hardness exihibited highest result also during pre - monsoon'10 $(607.2 \mathrm{mg} / \mathrm{l})$ at study site - III followed by study site-IV (482.2 mg/l during post-monsoon’08 - 09), study site-II (387.2 mg/l during pre-monsoon’09) and study site-I (332.8 mg/l during monsoon'10). The chloride content was found to be higher at study site-III (793.4 mg/l during monsoon’09) than other three sites. After reviewing the values of both chloride and conductivity of four study sites, chloride was found to be directly co - related with conductivity. Lowest values of both BOD (3.9 mg/l) and COD (26.6 mg/l) were recorded at study site - I during post - monsoon'08 - 09 followed by study site-IV, study site-II and study site-III (Table 1). The highest concentrations of $\mathrm{Pb}$ and $\mathrm{Hg}$ (water) were found during post-monsoon at study site-III followed by study site-II, study site-IV and study site-I. The Cr 
Table 1. Total number of species of different groups recorded from study site-I to IV during 2008-2011.

\begin{tabular}{|c|c|c|c|c|c|}
\hline Zooplankton Group & Total no. of Species & S-I & S-II & S-III & S-IV \\
\hline Rotifera & 11 & 7 & 5 & 5 & 5 \\
\hline Cladocera & 6 & 4 & 1 & 3 & 3 \\
\hline Copepoda & 4 & 3 & 1 & 2 & 2 \\
\hline TOTAL & 21 & 14 & 7 & 10 & 10 \\
\hline
\end{tabular}

content of water was found to be higher at study site-III during post-monsoon'08 - 09) than other three study sites while the highest value of Cd (water) was estimated during monsoon'08 at study site-II followed by study site-III, study site-IV and study site-I (Figure 2).

\subsection{Species Composition of Zooplankton}

A total number of 21 species of zooplankton belonging to three major taxa (rotifera, copepod and cladocera) were recorded during the period of investigation (July, 2008 - June, 2011). Highest number of species (14) was recorded at study site-III, which was supplied with nutrient rich water after being phytoremediated of raw sewage water. This was followed by study site-I and study site-II, both of which harboured 10 species and study site-IV receiving water after being drained from study site-III and used for pisciculture showed the occurrence of 7 species. The abundance of zooplankton was largely dominated by rotifers during the study period (Table 1).

The average relative importance of major taxonomic groups in the four sampling sites has been presented in Figure 3. The copepodan zooplankton species (Bosmina sp., and Kurzia sp.) were found at study site-I and similarly, the dominant rotiferan species (Brachionus foficula) and cladocera (Chydorus sp.) were present only at study site - III. Other rotiferan zooplankton (Brachionus patulus, Keratella tropica and Eucyclops sp.) were recorded only at study site - II. Moinadaphnia sp. was found to be present at all four study sites.

\subsubsection{Distribution and Seasonal Dynamics of Rotifera}

Rotiferan zooplankton was represented by 11 species belonging to 5 genera (Brachionus, Lecane, Polyartha, Filinia and Keratella). The relative abundance analysis has revealed that the rotifers represented 98.4\% (postmonsoon’10 - 11) at study site-III, 97.6\% (post-monsoon'08 - 09 and post-monsoon'10 - 11) at study site-II, 96.1\% (post-monsoon'09 - 10) at study ste-IV and 68.9\% (post-monsoon'10-11) at study site-I out of the total abundance of zooplankton (Table 2).

The seasonal variations in density of various genera of rotifers (no./l) in selected water - bodies have been presented in the Table 4. The population density of total rotifers ranged from 0.07 (no./l) during monsoon'09 and monsoon'10 to 3.7 (no./l) during post-monsoon'08 - 09 at study site-I, from 0.21 (no./l) during monsoon'10 to 6.2 (no./l) during post-monsoon'09 - 10 at study site-II, from a minimum 0.3 (no./l) during monsoon’08 to a maximum 8.92 (no./l) during post-monsoon'08 - 09 at study site-III and from 0.04 (no./l) during monsoon'08 to 4.3 (no./l) during post-monsoon'09 - 10 at study site-IV (Table 3). As the most dominant zooplanktonic component (64.1\% density) (Table 2 ) at the study site-III, rotifers exhibited significant seasonal variations (P < 0.0001, F 3.16) (Table 6). Maximum density of rotifers was recorded in post-monsoon which reached to minimum density in monsoon (Table 3).

\subsubsection{Distribution and Seasonal Dynamics of Cladocera}

Cladoceran zooplankton was represented by 6 genera (Chydorus, Alona, Ceriodaphnia, Moinadaphnia, Bosmina and Kurzia). At all the four study sites during the period of investigation, the cladocera constituted $61.2 \%$ (monsoon’10) at study site-III, 56.5\% (monsoon’08) at study site-IV, 57.9\% (post-monsoon’10 - 11) at study site-I and $77.6 \%$ (monsoon'10) at study site-II out of the total abundance of zooplankton (Table 2). The seasonal variations in density of various genera of cladocera (no./l) in the selected study sites have been presented in Table 4. The population density of total cladocera ranged from 1.17 (no./l) during post-monsoon’08 - 09 to 4.03 no./l during monsoon'08 and at study site-I and in case of study site - II from 0.13 (no./l) during post-monsoon’08 09 to 2.12 (no./l) during monsoon'10, from a minimum 0.09 (no./l) during post-monsoon’09 - 10 to a 

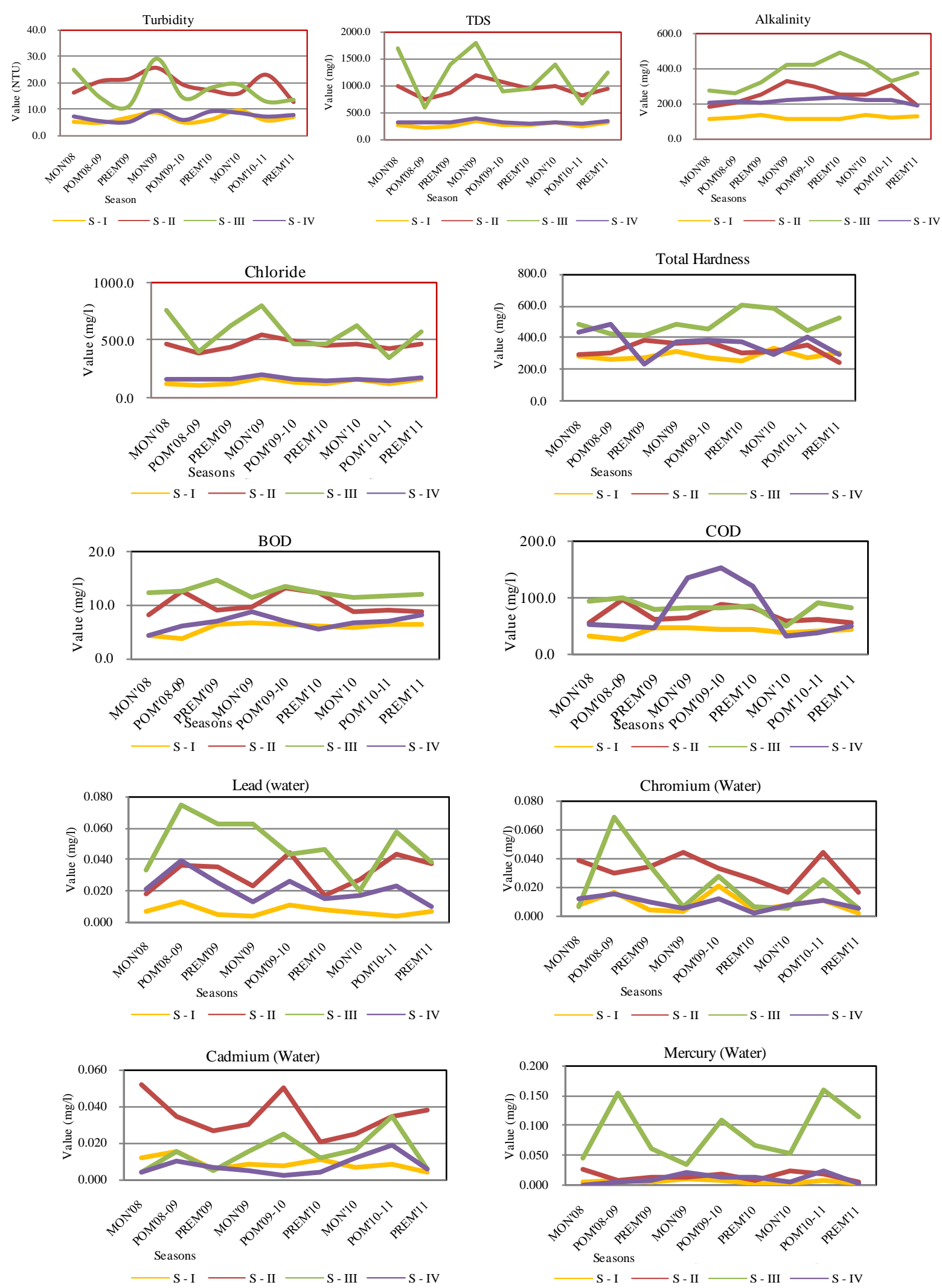

Figure 2. Seasonal variation in different physicochemical parameters of water observed during 2008-2011 of four study sites. 

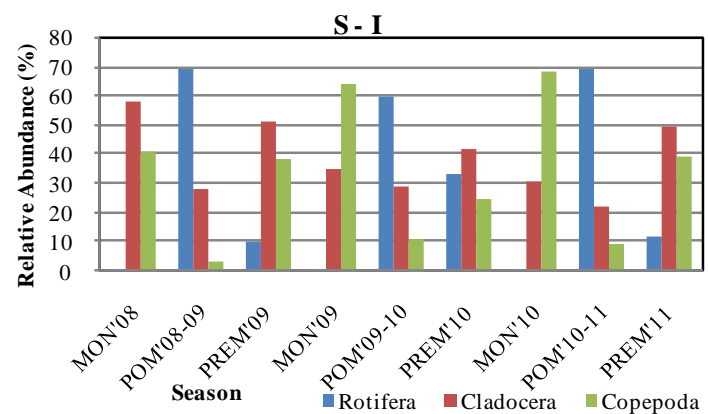

S - III

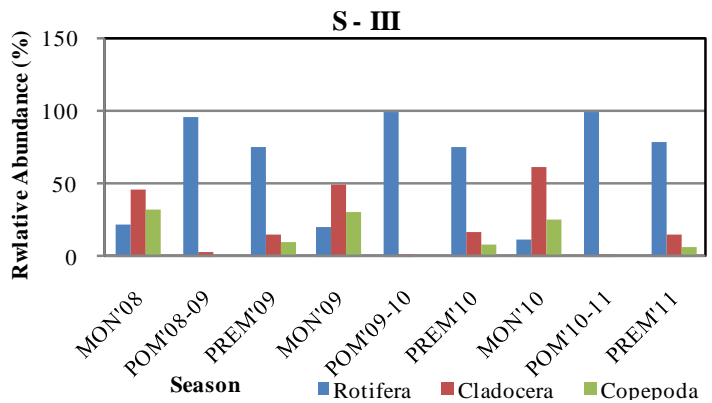

S - II


Figure 3. Seasonal variation in relative abundance (\%) of different Zooplanktonic groups observed during 2008 -2011 of four study sites.

Table 2. Range and average in relative abundance (\%) of different Zooplanktonic groups observed during $2008-2011$ of four study sites.

\begin{tabular}{cccc}
\hline Study Sites & Zooplanktonic Groups & Range & Average \\
\hline \multirow{2}{*}{ I } & Rotifera & $0.7-68.9$ & 28.4 \\
& Cladocera & $22.1-57.9$ & 38.4 \\
& Copepoda & $3.5-68.2$ & 33.2 \\
II & Rotifera & $7.6-97.6$ & 55.4 \\
& Cladocera & $2.2-77.6$ & 34.6 \\
& Copepoda & $0.2-34.0$ & 10.1 \\
III & Rotifera & $12.7-98.4$ & 64.1 \\
& Cladocera & $1.0-61.2$ & 22.8 \\
& Copepoda & $0.3-32.5$ & 13.1 \\
& Rotifera & $1.6-96.1$ & 49.6 \\
\end{tabular}

Table 3. Range and average of the density (no./l) of major taxa of four study sites during 2008-2011.

\begin{tabular}{cccc}
\hline Study Sites & Zooplanktonic Groups & Range & Average \\
\hline \multirow{2}{*}{ I } & Rotifera & $0.07-3.7$ & 1.7 \\
& Cladocera & $1.17-4.03$ & 2.82 \\
& Copepoda & $0.19-6.75$ & 2.69 \\
II & Rotifera & $0.21-6.34$ & 2.86 \\
& Cladocera & $0.13-2.12$ & 1.03 \\
& Copepoda & $0.01-0.65$ & 0.26 \\
III & Rotifera & $0.34-8.92$ & 5.13 \\
& Cladocera & $0.09-1.64$ & 0.87 \\
& Copepoda & $0.03-0.85$ & 0.48 \\
& Rotifera & $0.04-4.3$ & 2.21 \\
& Cladocera & $0.16-1.28$ & 0.62 \\
\hline
\end{tabular}


Table 4. Seasonal variations in average density (no./l) of different species at four study sites during 2008-2011.

\begin{tabular}{|c|c|c|c|c|c|c|c|c|c|}
\hline S-I & MON'08 & POM'08-09 & PREM'09 & MON'09 & POM'09-10 & PREM'10 & MON'10 & POM'10-11 & PREM'11 \\
\hline Brachionus falcatus & 0.00 & 0.30 & 0.06 & 0.01 & 0.33 & 0.51 & 0.02 & 0.64 & 0.14 \\
\hline Brachionus rubens & 0.02 & 0.74 & 0.05 & 0.00 & 0.83 & 0.58 & 0.01 & 0.53 & 0.27 \\
\hline Brachionus quadridentatus & 0.03 & 0.86 & 0.20 & 0.00 & 0.80 & 0.57 & 0.04 & 0.89 & 0.08 \\
\hline Lecane papuana & 0.01 & 0.87 & 0.10 & 0.04 & 0.74 & 0.87 & 0.00 & 0.96 & 0.14 \\
\hline Polyartha vulgaris & 0.01 & 0.93 & 0.30 & 0.03 & 0.55 & 0.31 & 0.00 & 0.64 & 0.33 \\
\hline Moinadaphnia sp. & 0.95 & 0.12 & 0.92 & 1.02 & 0.27 & 0.83 & 0.77 & 0.31 & 1.36 \\
\hline Bosmina sp. & 1.17 & 1.08 & 1.96 & 0.58 & 0.95 & 1.96 & 0.57 & 0.64 & 1.82 \\
\hline Kurzia sp. & 1.91 & 0.31 & 0.66 & 1.40 & 0.35 & 0.79 & 1.73 & 0.23 & 0.77 \\
\hline Mesocyclops sp. & 1.20 & 0.12 & 1.25 & 2.90 & 0.52 & 1.26 & 3.05 & 0.16 & 1.33 \\
\hline Megacyclops sp. & 1.66 & 0.07 & 1.40 & 2.57 & 0.11 & 0.83 & 3.70 & 0.32 & 1.77 \\
\hline S-II & MON'08 & POM'08-09 & PREM'09 & MON'09 & POM'09-10 & PREM'10 & MON'10 & POM'10-11 & PREM'11 \\
\hline Brachionus angularis & 0.07 & 1.27 & 1.03 & 0.02 & 1.35 & 0.45 & 0.05 & 1.43 & 0.51 \\
\hline Brachionus patulus & 0.01 & 1.66 & 0.66 & 0.06 & 1.42 & 0.24 & 0.11 & 1.36 & 0.41 \\
\hline Polyartha vulgaris & 0.00 & 1.04 & 0.63 & 0.02 & 1.29 & 0.64 & 0.02 & 1.25 & 0.75 \\
\hline Filinia longiseta & 0.09 & 0.63 & 0.58 & 0.05 & 1.39 & 0.09 & 0.00 & 1.43 & 0.40 \\
\hline Keratella tropica & 0.09 & 0.78 & 0.14 & 0.14 & 0.73 & 0.34 & 0.03 & 0.87 & 0.27 \\
\hline Alona sp. & 0.19 & 0.00 & 0.24 & 0.33 & 0.00 & 0.27 & 0.77 & 0.02 & 0.40 \\
\hline Ceriodaphnia sp. & 0.59 & 0.00 & 0.67 & 0.37 & 0.06 & 0.97 & 0.81 & 0.08 & 0.39 \\
\hline Moinadaphnia sp. & 0.49 & 0.13 & 0.36 & 0.29 & 0.13 & 0.74 & 0.55 & 0.04 & 0.41 \\
\hline Heliodiaptomus sp. & 0.10 & 0.00 & 0.07 & 0.30 & 0.01 & 0.09 & 0.26 & 0.00 & 0.12 \\
\hline Eucyclops sp. & 0.26 & 0.01 & 0.10 & 0.35 & 0.00 & 0.27 & 0.15 & 0.02 & 0.28 \\
\hline S-III & MON'08 & POM'08-09 & PREM'09 & MON'09 & POM'09-10 & PREM'10 & MON'10 & POM'10-11 & PREM'11 \\
\hline Brachionus angularis & 0.12 & 0.96 & 0.56 & 0.07 & 1.12 & 0.97 & 0.00 & 1.22 & 0.79 \\
\hline Brachionus foficula & 0.08 & 2.05 & 0.90 & 0.05 & 1.19 & 0.94 & 0.08 & 1.11 & 0.99 \\
\hline Brachionus diversicornis & 0.01 & 1.19 & 1.11 & 0.00 & 1.44 & 1.17 & 0.01 & 1.13 & 0.98 \\
\hline Brachionus falcatus & 0.01 & 1.23 & 1.27 & 0.02 & 1.52 & 2.26 & 0.02 & 1.64 & 1.33 \\
\hline Lecane papuana & 0.05 & 1.38 & 0.74 & 0.06 & 1.40 & 0.62 & 0.01 & 1.15 & 0.89 \\
\hline Polyartha vulgaris & 0.01 & 1.65 & 0.85 & 0.09 & 0.76 & 0.91 & 0.17 & 0.85 & 0.52 \\
\hline Filinia longiseta & 0.07 & 0.47 & 0.21 & 0.22 & 1.10 & 0.45 & 0.05 & 1.32 & 0.65 \\
\hline Chydorus sp. & 0.20 & 0.13 & 0.32 & 0.23 & 0.02 & 0.17 & 0.27 & 0.04 & 0.26 \\
\hline Alona sp. & 0.13 & 0.05 & 0.25 & 0.29 & 0.03 & 0.30 & 0.53 & 0.07 & 0.38 \\
\hline Ceriodaphnia sp. & 0.20 & 0.09 & 0.29 & 0.40 & 0.04 & 0.45 & 0.42 & 0.00 & 0.26 \\
\hline Moinadaphnia sp. & 0.17 & 0.02 & 0.26 & 0.25 & 0.00 & 0.65 & 0.42 & 0.01 & 0.24 \\
\hline Mesocyclops sp. & 0.24 & 0.02 & 0.27 & 0.23 & 0.02 & 0.27 & 0.22 & 0.00 & 0.23 \\
\hline Megacyclops sp. & 0.12 & 0.04 & 0.29 & 0.18 & 0.03 & 0.35 & 0.31 & 0.02 & 0.16 \\
\hline Heliodiaptomus sp. & 0.14 & 0.02 & 0.29 & 0.32 & 0.01 & 0.22 & 0.17 & 0.01 & 0.15 \\
\hline S-IV & MON'08 & POM'08-09 & PREM'09 & MON'09 & POM'09-10 & PREM'10 & MON'10 & POM'10-11 & PREM'11 \\
\hline Brachionus diversicornis & 0.00 & 0.71 & 0.97 & 0.03 & 0.97 & 0.55 & 0.01 & 0.49 & 0.29 \\
\hline Brachionus falcatus & 0.00 & 0.92 & 0.42 & 0.00 & 0.34 & 0.54 & 0.02 & 0.49 & 0.74 \\
\hline Brachionus rubens & 0.02 & 0.85 & 0.75 & 0.01 & 0.92 & 0.56 & 0.00 & 0.67 & 0.38 \\
\hline Brachionus quadridentatus & 0.02 & 1.07 & 0.71 & 0.00 & 1.37 & 0.63 & 0.03 & 0.99 & 0.16 \\
\hline Filinia longiseta & 0.00 & 0.73 & 0.26 & 0.02 & 0.72 & 0.63 & 0.03 & 0.86 & 0.04 \\
\hline Moinadaphnia sp. & 0.85 & 0.19 & 0.39 & 0.97 & 0.17 & 1.28 & 1.13 & 0.16 & 0.45 \\
\hline Mesocyclops sp. & 0.62 & 0.09 & 1.33 & 2.52 & 0.00 & 2.18 & 3.02 & 0.15 & 1.22 \\
\hline
\end{tabular}


maximum 1.64 (no./l) during monsoon’10 at study site-III, from 0.16 (no./l) during post-monsoon’09 - 10 to 1.28 (no./l) during pre-monsoon'10 at study site-IV (Table 3). The density of cladocerans, the second dominant zooplanktonic component (38.4\%) (Table 2) at study site-I, also showed significant seasonal variations (P < $0.0001 \mathrm{~F}$ 15.46) (Table 6). The minimum density of cladocera was recorded during post-monsoon which reached to maximum during monsoon (Table 3).

\subsubsection{Distribution and Seasonal Dynamics of Copepoda}

Copepodan zooplankton was represented by 4 genera (Mesocyclops, Megacyclops, Heliodiaptomus and Eucyclops). The relative abundance analysis has revealed the occurrence of copepoda in tune with 32.5\% (monsoon’08) at study site-III, 71.3\% (monsoon’09 and monsoon’10) at study site-IV, 68.2\% (monsoon’10) at study site-I and 34.0\% (monsoon’09) at study site-IV out of the total abundance of zooplankton (Table 2).

The seasonal variations in density of various genera of copepoda (no./l) in selected study sites have been showed in the Table 4. The population density of total copepods ranged from 0.19 (no./l) during post-monsoon’08 - 09 to 6.75 (no./l) during monsoon’10 at study site-I, from 0.01 (no./l) during post-monsoon’08 - 09 and post-monsoon'09 - 10 to 0.65 (no./l) during monsoon’09 at study site-II, from a minimum 0.03 (no./l) during post-monsoon'09 - 10 a maximum 0.85 (no./l) during pre-monsoon’09 and pre-monsoon'10 at study site-III and from 0.00 during post-monsoon'09 - 10 to 3.02 (no./l) during monsoon'10 at study site-IV (Table 3). Copepoda the third and lowest zooplanktonic component (33.2\%) (Table 2) at study site-I also showed significant seasonal variations ( $\mathrm{P}<0.0001 \mathrm{~F}$ 6.72) (Table 6). Minimum density of copepoda was recorded in post-monsoon which reached to maximum peak in monsoon (Table 3 ).

The present study has highlighted that the diversity and density (Figure 3 and Figure 4) of rotifera reached maximum levels during post-monsoon season followed by pre-monsoon and monsoon. The present study also revealed that the presence of this taxa of zooplankton at all study sites through different months and seasons of year, although population density drastically reduced during monsoon. This study also highlights the presence of Brachionus patulus and Keratella tropica in the mostly polluted water body such as study site-II.

\subsection{Species Pollution Value (SPV) and Community Pollution Value (CPV)}

SPV computed out of distribution 21 different zooplanktonic species (rotifera- 1; cladocera-6; copepoda-4) during different seasons (9 seasons) of 3 consecutive years (2008-2011) have highlighted maximum result (2.87)
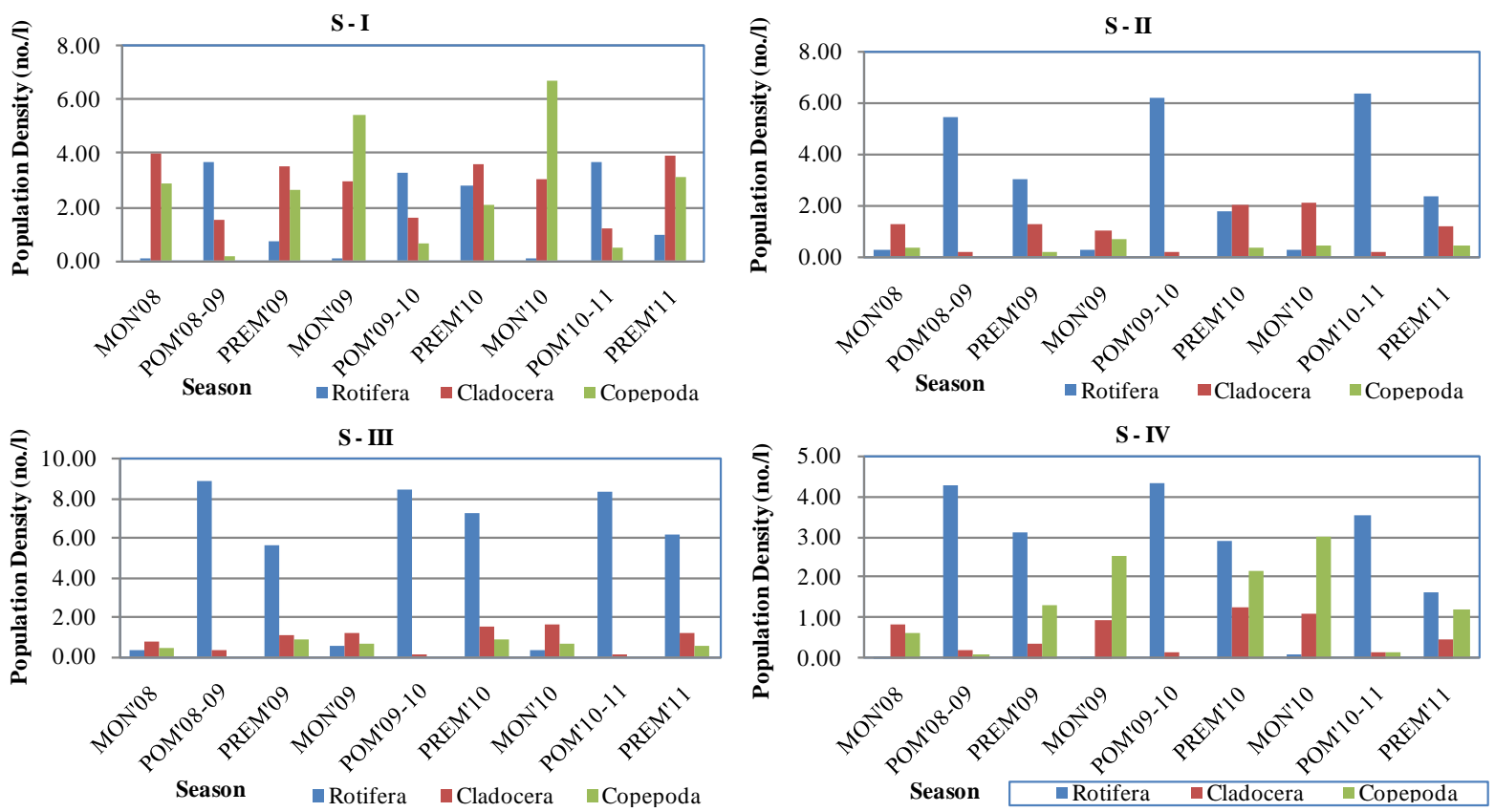

Figure 4. Seasonal variation in population density (no./l) of different Zooplanktonic groups observed during 2008-2011 of four study sites. 
jointly by Brachionus patulus during post-monsoon (2009-2010) and Keratella tropica during post-monsoon (2009-2010) and lowest (1.92) jointly by Brachionus rubens during monsoon (2008) and Brachionus quadridentatus during monsoon (2008) (Table 5).

$\mathrm{CPV}$ deducted based on the occurrence of different zooplankton species, showed maximum value at study site-II (2.68) during post-monsoon'09 - 10 followed by study site-III (2.54) during post-monsoon'09 - 10, study site-IV (2.29) during monsoon'09 and study site-I (2.30) during monsoon'09 (Figure 5). Seasonal variations of CPV of four study sites [during the study period (July, 2008 - June, 2011)] showed significant seasonal variations (P < 0.0001 F 71.06) (Table 6).

Table 5. Species pollution value (SPV) of Zooplanktonic species four study sites during 2008-2011.

\begin{tabular}{|c|c|c|c|c|c|c|c|c|c|c|}
\hline Family & Name & MON'08 & POM'08-09 & PREM'09 & MON'09 & POM'09-10 & PREM'10 & MON'10 & POM'10-11 & PREM'11 \\
\hline \multirow{7}{*}{$\begin{array}{c}\text { Rotifera } \\
" "\end{array}$} & Brachionus angularis & 2.59 & 2.61 & 2.59 & 2.63 & 2.78 & 2.58 & 2.48 & 2.65 & 2.56 \\
\hline & Brachionus foficula & 2.50 & 2.53 & 2.64 & 2.65 & 2.69 & 2.58 & 2.57 & 2.70 & 2.52 \\
\hline & $\begin{array}{l}\text { Brachionus } \\
\text { diversicornis }\end{array}$ & 2.50 & 2.33 & 2.35 & 2.15 & 2.35 & 2.26 & 2.34 & 2.46 & 2.31 \\
\hline & Brachionus falcatus & 2.50 & 2.20 & 2.23 & 2.37 & 2.23 & 2.20 & 2.23 & 2.31 & 2.20 \\
\hline & Brachionus rubens & 1.92 & 2.04 & 2.02 & 2.15 & 2.00 & 2.00 & 2.01 & 2.11 & 2.04 \\
\hline & $\begin{array}{l}\text { Brachionus } \\
\text { quadridentatus }\end{array}$ & 1.92 & 2.04 & 2.02 & 0.00 & 2.00 & 2.00 & 2.06 & 2.11 & 2.04 \\
\hline & Brachionus patulus & 2.67 & 2.69 & 2.54 & 2.61 & 2.87 & 2.58 & 2.48 & 2.60 & 2.59 \\
\hline$"$ & Lecane papuana & 2.23 & 2.24 & 2.31 & 2.37 & 2.34 & 2.32 & 2.57 & 2.35 & 2.25 \\
\hline$"$ & Polyartha vulgaris & 2.23 & 2.39 & 2.39 & 2.45 & 2.52 & 2.41 & 2.53 & 2.43 & 2.36 \\
\hline \multirow[t]{2}{*}{ " } & Filinia longiseta & 2.59 & 2.45 & 2.41 & 2.47 & 2.52 & 2.37 & 2.34 & 2.46 & 2.40 \\
\hline & Keratella tropica & 2.67 & 2.69 & 2.54 & 2.61 & 2.87 & 2.58 & 2.48 & 2.60 & 2.59 \\
\hline \multirow{6}{*}{$\begin{array}{c}\text { Cladocera } \\
"\end{array}$} & Chydorus sp. & 2.50 & 2.53 & 2.64 & 2.65 & 2.69 & 2.58 & 2.57 & 2.70 & 2.52 \\
\hline & Allona sp. & 2.59 & 2.53 & 2.59 & 2.63 & 2.69 & 2.58 & 2.53 & 2.65 & 2.56 \\
\hline & Ceriodaphnia sp. & 2.59 & 2.53 & 2.59 & 2.63 & 2.78 & 2.58 & 2.53 & 2.60 & 2.56 \\
\hline & Moinadaphnia sp. & 2.25 & 2.32 & 2.31 & 2.38 & 2.29 & 2.29 & 2.29 & 2.38 & 2.30 \\
\hline & Bosmina sp. & 1.95 & 1.94 & 1.98 & 2.09 & 2.00 & 2.06 & 2.01 & 1.99 & 1.98 \\
\hline & Kurzia sp. & 1.95 & 1.94 & 1.98 & 2.09 & 2.00 & 2.06 & 2.01 & 1.99 & 1.98 \\
\hline \multirow{4}{*}{$\begin{array}{c}\text { Copepoda } \\
"\end{array}$} & Mesocyclops sp. & 2.11 & 2.20 & 2.23 & 2.30 & 2.35 & 2.19 & 2.23 & 2.11 & 2.20 \\
\hline & Megacyclops sp. & 2.23 & 2.24 & 2.31 & 2.37 & 2.35 & 2.32 & 2.29 & 2.35 & 2.25 \\
\hline & Heliodiaptomus sp. & 2.59 & 2.53 & 2.59 & 2.63 & 2.78 & 2.58 & 2.53 & 2.70 & 2.56 \\
\hline & Eucyclops sp. & 2.67 & 2.69 & 2.54 & 2.61 & 0.00 & 2.58 & 2.48 & 2.60 & 2.59 \\
\hline
\end{tabular}

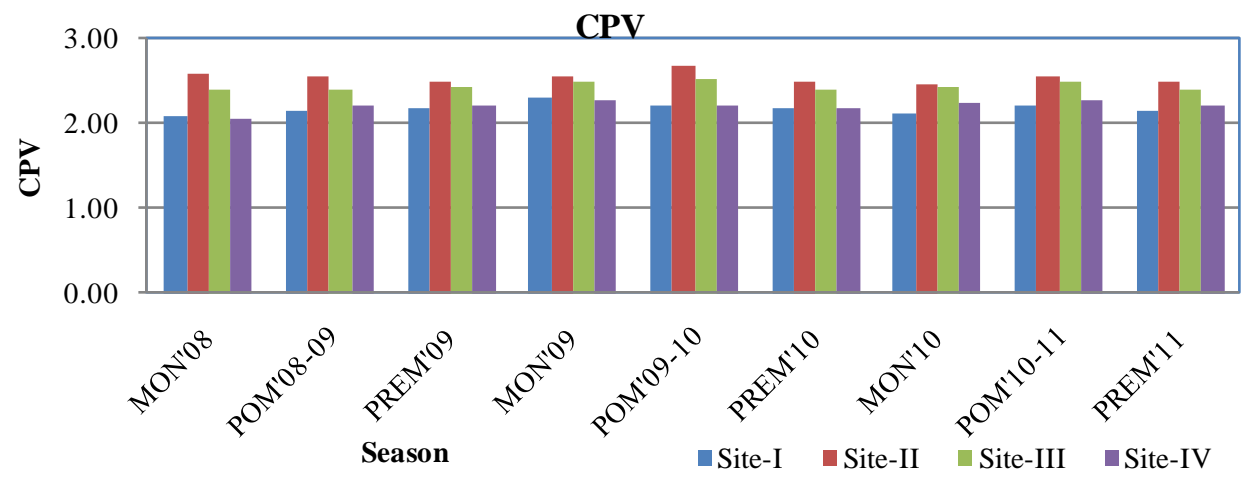

Figure 5. Seasonal variation in CPV of different four study sites observed during 2008-2011. 
Table 6. ANOVA of Seasonal variations in average density (no./l) of major groups and CPV of four sites during 2008-2011.

\begin{tabular}{cc}
\hline & $\mathrm{F}$ \\
\hline Rotifera & 3.16 \\
Cladocera & 15.46 \\
Copepoda & 6.72 \\
$\mathrm{CPV}$ & 71.06 \\
\hline
\end{tabular}

\subsubsection{Pearson's Correlation of Physicochemical Parameters of Water with Zooplankton}

Amongst the density of total zooplanktons, cladocera was correlated positively with water-temperature at all three study sites except study site-IV, while rotifers were negatively correlated with water-temperature at study site-I followed by study site-II and study site-III. Copepods also showed positive correlation with water-temperature at study site-II followed by study site-III and study site-IV. Both cladocera (at study site-IV) and copepoda (at study site-I) exhibited significant positive correlation $(p<0.01)$ with turbidity, whereas rotifera was negatively correlated. In case of both TDS and conductivity, rotifera showed significant negative correlation at study site-III followed by study site-I and study site-IV, while copepods showing significant positive correlation at study site-I followed by study site-II and study site-III. Chloride showed highly significant correlationship at 0.01 level together with rotifera at study site-III $\left(\mathrm{r}=-0.898^{* *}\right)$ and copepoda at study site-I $\left(\mathrm{r}=0.836^{* *}\right)$. Rotifera displayed negative correlation $\left(\mathrm{r}=-0.687^{*}\right)$, while both cladocera (at study site-III; $\mathrm{r}=0.750^{*}$ ) and copepoda (at study site-I; $\mathrm{r}=0.854^{* *}$ ) exhibited significant positive correlation with total hardness. No significant relationship was found in between few physicochemical parameters of water like, $\mathrm{pH}$, Alkalinity, DO and BOD and zooplanktonic species at all four study sites (Table 7).

Positive correlation was exhibited in between rotifera and heavy metals, whereas rotifera displayed negative correlation with other water parameter. $\mathrm{Pb}$ (at study site-II; $\mathrm{r}=0.835^{* *}$ ) and $\mathrm{Hg}$ (at study site-III; $\mathrm{r}=0.821^{* *}$ ) of water showed highly significant correlationship at 0.01 level with rotifera. Both cladocera and copepoda exhibited significant positive correlation with $\mathrm{Pb}, \mathrm{Cr}$ and $\mathrm{Hg}$ (of water), while $\mathrm{Cd}$ (of water) was found to bear significant negative correlation with only copepoda $(p<0.05)$ at study site-III. At study site-I, both Brachionus falcatus and Bosmina sp. have no significant relation with the physicochemical parameters of water.

\subsubsection{Pearson's Correlation of Physicochemical Parameters of Water with Community Pollution Value (CPV)}

Amongst all physicochemical parameters of water, both water-temperature (at study site-II) and dissolved oxygen (DO) (at study site-I and study site - IV) showed significant negative correlationship with CPV. On the other hand, CPV exhibited significant positive correlation with $\mathrm{pH}$ (at study site-IV), BOD (at study site-IV), COD (at study site-I), Cd (at study site-II and study site-III) and Hg (at study site-I) (Table 8).

\subsection{Similarity Indices}

Similarity indices of different study sites with regard to their zooplanktonic species composition revealed maximum similarity (58.8\%) in between study site-IV and study site-I followed by $58.3 \%$ in between study site-III and study site-II, $50 \%$ in between study site-III and study site-I, $47.6 \%$ in between study site-III and study site-IV, 23.5\% in between study Site - IV and study site - II and lowest $20 \%$ was observed in between study site-II and study site-I (Table 9).

On the basis of the occurrence of rotifera, maximum similarity (60\%) was recorded in between study site-IV and study site-II and that of minimum (20\%) was found in between study site-I and study site-II and study site-III and study site-IV (Table 9).

According to the occurrence of cladocera, maximum similarity $(85.71 \%)$ was recorded in between study site-II and study site-III and that of minimum (28.57\%) was found in between study site-I and study site-III (Table 9).

Depending on the occurrence of copepoda, maximum similarity (66.67\%) was recorded in between study site-I 
Table 7. Pearson correlation between physicochemical parameters of water and major groups of Zooplankton at four study sites during 2008-2011.

\begin{tabular}{|c|c|c|c|c|c|c|c|}
\hline S-I & Rotifera & Cladocera & Copepoda & S-II & Rotifera & Cladocera & Copepoda \\
\hline Wtemp & $-0.771^{*}$ & $0.943^{* *}$ & 0.66 & Wtemp & $-0.787^{*}$ & $0.876^{* *}$ & $0.727^{*}$ \\
\hline Turbdt & $-0.683^{*}$ & 0.359 & $0.926^{* *}$ & Turbdt & 0.276 & -0.484 & -0.111 \\
\hline $\mathrm{pH}$ & 0.155 & 0.144 & -0.275 & $\mathrm{pH}$ & 0.439 & -0.43 & -0.288 \\
\hline TDS & $-0.790^{*}$ & 0.516 & $0.909^{* *}$ & TDS & -0.538 & 0.269 & $0.688^{*}$ \\
\hline Alk & -0.464 & 0.29 & 0.457 & Alk & 0.227 & -0.246 & 0.029 \\
\hline $\mathrm{Cl}$ & -0.663 & 0.359 & $0.836^{* *}$ & $\mathrm{Cl}$ & -0.51 & 0.255 & $0.695^{*}$ \\
\hline $\mathrm{TH}$ & $-0.687^{*}$ & 0.225 & $0.854^{* *}$ & $\mathrm{TH}$ & 0.341 & -0.335 & -0.282 \\
\hline Condtvt & $-0.790^{*}$ & 0.521 & $0.907^{* *}$ & Condtvt & -0.512 & 0.244 & $0.700^{*}$ \\
\hline DO & 0.121 & -0.014 & -0.434 & DO & -0.551 & 0.454 & 0.433 \\
\hline BOD & -0.165 & 0.134 & 0.28 & BOD & 0.552 & -0.388 & -0.489 \\
\hline COD & -0.181 & 0.164 & 0.258 & COD & 0.532 & -0.406 & -0.508 \\
\hline $\mathrm{WPb}$ & 0.614 & -0.401 & -0.616 & $\mathrm{WPb}$ & $0.835^{* *}$ & $-0.700^{*}$ & $-0.710^{*}$ \\
\hline WCr & $0.686^{*}$ & $-0.803^{* *}$ & -0.594 & WCr & 0.245 & -0.558 & -0.145 \\
\hline WCd & 0.434 & -0.33 & -0.425 & WCd & 0.229 & -0.505 & -0.266 \\
\hline WHg & 0.299 & -0.605 & -0.29 & WHg & -0.178 & 0.098 & -0.064 \\
\hline S-III & Rotifera & cladocera & Copepoda & S-IV & Rotifera & cladocera & Copepoda \\
\hline WTemp & $-0.891^{* * *}$ & $0.790^{*}$ & $0.806^{* *}$ & WTemp & -0.497 & 0.643 & $0.725^{*}$ \\
\hline Turbdt & $-0.800^{* *}$ & 0.324 & 0.358 & Turbdt & $-0.667^{*}$ & $0.817^{* *}$ & $0.754^{*}$ \\
\hline TDS & $-0.906^{* *}$ & 0.544 & $0.680^{*}$ & TDS & $-0.685^{*}$ & 0.304 & 0.474 \\
\hline Alk & -0.082 & 0.555 & 0.434 & Alk & 0.168 & 0.377 & 0.225 \\
\hline $\mathrm{Cl}$ & $-0.898^{* *}$ & 0.496 & 0.636 & $\mathrm{Cl}$ & -0.65 & 0.31 & 0.51 \\
\hline $\mathrm{TH}$ & -0.32 & $0.750^{*}$ & 0.524 & $\mathrm{TH}$ & 0.208 & -0.184 & -0.53 \\
\hline Condtvt & $-0.886^{* *}$ & 0.525 & $0.671^{*}$ & Condtvt & $-0.697^{*}$ & 0.336 & 0.501 \\
\hline $\mathrm{DO}$ & -0.28 & 0.139 & -0.159 & $\mathrm{DO}$ & -0.009 & 0.191 & -0.267 \\
\hline BOD & 0.39 & -0.216 & 0.032 & BOD & -0.032 & -0.233 & 0.214 \\
\hline COD & 0.448 & -0.612 & -0.432 & COD & 0.134 & 0.173 & 0.072 \\
\hline $\mathrm{WPb}$ & 0.489 & -0.416 & -0.251 & $\mathrm{WPb}$ & 0.664 & -0.638 & -0.659 \\
\hline WCr & 0.611 & -0.592 & -0.553 & WCr & 0.37 & -0.661 & $-0.737^{*}$ \\
\hline WCd & 0.404 & -0.551 & $-0.674^{*}$ & WCd & 0.132 & -0.281 & -0.104 \\
\hline WHg & $0.821^{* *}$ & $-0.703^{*}$ & $-0.822^{* *}$ & WHg & 0.258 & -0.141 & -0.03 \\
\hline
\end{tabular}

*Correlation is significant at the 0.05 level $(p<0.05)$. ${ }^{*}$ Correlation is significant at the 0.01 level $(p<0.01)$. 
Table 8. Pearson Correlation between physicochemical parameters of water and CPV at four study sites during 2008-2011.

\begin{tabular}{ccccc}
\hline & & & & \\
& & & \\
CPV & S-I & S-II & -0.21 \\
\hline WTemp & -0.215 & $-0.758^{*}$ & -0.39 & 0.108 \\
Turbdt & 0.299 & 0.277 & 0.002 & $0.731^{*}$ \\
pH & -0.647 & 0.344 & 0.555 & 0.162 \\
TDS & 0.26 & 0.274 & -0.135 & 0.229 \\
Alk & -0.231 & 0.325 & 0.307 & 0.231 \\
Cl & 0.403 & 0.251 & -0.166 & -0.232 \\
TH & 0.039 & 0.393 & -0.319 & 0.162 \\
Condt & 0.257 & 0.244 & -0.106 & $-0.738^{*}$ \\
DO & $-0.780^{*}$ & -0.545 & -0.332 & $0.785^{*}$ \\
BOD & 0.655 & 0.468 & 0.05 & 0.139 \\
COD & $0.674^{*}$ & 0.395 & -0.062 & 0.007 \\
WPb & -0.323 & 0.37 & 0.168 & -0.222 \\
WCr & -0.062 & 0.536 & -0.021 & 0.448 \\
WCd & -0.21 & $0.763^{*}$ & $0.749^{*}$ & 0.656 \\
WHg & $0.670^{*}$ & 0.265 & 0.128 & \\
\hline
\end{tabular}

Table 9. Similarity indices between four different study sites (2008-2011).

\begin{tabular}{|c|c|c|c|c|}
\hline Zooplankton & S-I & S-II & S-III & S-IV \\
\hline S-I & $* * *$ & 20 & 50 & 58.8 \\
\hline S-II & $* * *$ & $* * *$ & 58.3 & 23.5 \\
\hline S-III & $* * *$ & $* * *$ & $* * *$ & 47.6 \\
\hline S-IV & $* * *$ & $* * *$ & $* * *$ & $* * *$ \\
\hline Rotifera & S-I & S-I & S-I & S-I \\
\hline S-I & $* * *$ & 20 & 50 & 60 \\
\hline S-II & $* * *$ & $* * *$ & 50 & 20 \\
\hline S-III & $* * *$ & $* * *$ & $* * *$ & 50 \\
\hline S-IV & $* * *$ & $* * *$ & $* * *$ & $* * *$ \\
\hline Cladocera & S-I & S-I & S-I & S-I \\
\hline S-I & $* * *$ & 33.35 & 28.57 & 50 \\
\hline S-II & $* * *$ & $* * *$ & 85.71 & 50 \\
\hline S-III & $* * *$ & $* * *$ & $* * *$ & 40 \\
\hline S-IV & $* * *$ & $* * *$ & $* * *$ & $* * *$ \\
\hline Copepoda & S-I & S-I & S-I & S-I \\
\hline S-I & $* * *$ & 0.00 & 80 & 66.67 \\
\hline S-II & $* * *$ & $* * *$ & 40 & 0.00 \\
\hline S-III & $* * *$ & $* * *$ & $* * *$ & 50 \\
\hline S-IV & $* * *$ & $* * *$ & $* * *$ & $* * *$ \\
\hline
\end{tabular}

*** mentioned here have been given to form the matrix of the similarity indices. It denotes neither any value nor any specific sign. 
and study site-IV and that of minimum (40\%) was found in between study site-II and study site-III. There were no similarity (with regard to copepoda composition) in between study site-I and study site-II and in between study site-II and study site-IV (Table 9).

\section{Discussion}

The present paper has generated considerable information with regard to the ecodynamics of four selected wetlands that have contrasting ecological features (study ste-I, study site-II, study site-III and study site-IV) and locate along East Kolkata Wetlands (EKW) of international significance taking into consideration of diversity and population density of zooplanktonic species of 3 major taxa viz. rotifera (5 genera and 11 species), cladocera (6 genera) and copepoda (4 genera) in relation to major water quality parameters. The biotic indices like Species Pollution Value (SPV) and Community Pollution Value (CPV) have been computed based on the basic ecological information on zooplanktonic taxa.

According to Index of Similarity, the highest similarity values of total zooplankton, rotifera and copepoda were observed between study site-I and study site-IV (58.8\%, 60\% and 66.67\%, respectively) while the highest similarity values of both total zooplankton and cladocera were observed between study site-II and study site-III (58.3\% and 85.71\%, respectively). Such results have appeared to identify the mode of similarities among different wetlands based on their biotic components. The findings of the present research have established the facts that study site-I tended to be more similar to study site-IV while study site-II is identical to study site-III.

The density of zooplankton fluctuated widely between the wetlands and was related to the nature of wetlands [28] [33]. As population density of total rotifera was found to be maximum at study site-III followed by study site-II, study site-IV and study site-I, whereas the population densities of both cladocera and copepoda registered the highest results at study site-I. It can be inferred out of such habitat preferences, the rotifera may be assigned as the good indicator species of a newly ecorestored (through phytoremediation of sewage) water bodies (study site-III and study site-IV) [34] while the dominance of both cladocera and copepoda has indicated the ecologically stable and undisturbed water body (study site-I). Moreover, the differential occurrences of rotifera in respect of their density and diversity are supposed to be due to the cumulative impact of water quality parameters in one hand, and predation pressure because of pisciculture (at study site-IV) on the other. Highest density was recorded from raw sewage pond (study site-III) where very high organic load and comparatively lowest predation pressure (no pisciculture, only phytoremediation) resulted in the increased density of zooplankton. The impact of predation was quite evident at fish culture pond (study site-IV) where the density was considerably low. The higher abundance of rotifera followed by cladocera and copepoda at study sites III and II reflected the power of the tolerance of these three major taxa of zooplankton against the multifarious stresses (anthropogenic and environmental) imposed on those wetlands which had paved the way of treating these taxa as indicator species.

It can be stated that the CPV represents higher the degree of pollution [30] [35]. As CPV was calculated from the distribution of zooplanktonic species, the present study tended to highlight the pollution status of water bodies. CPV of study site-II showed the highest value followed by study site-III, study site-IV and study site-I during July, 2008-June, 2011 (Figure 4). A range of CPV was established on the basis of the evaluation of the degree of pollution based on the analysis of the biological and physicochemical parameters from where the status of pollution can be ascertained especially for the tropical climatic condition [35]. Accordingly study site-III and study site-II showed the highest degree of pollution. It can be inferred that the study site-II revealed higher CPV (2.68) indicating higher pollution load of this aquatic body while study site-I and study Site-IV were unpolluted because of their less CPV (2.05 at study site-IV during monsoon'08 and 2.09 at study site-I during monsoon'08) which in turn corroborated with the findings of physicochemical parameters which tended to remain always with permissible limit. Moreover, CPV obtained from the distributional patterns of zooplanktonic species of four study sites have revealed that the study site - II and study site - III were grossly polluted when compared with other two study sites (study sites-I and IV). However, the calculation of CPV did not take into account of species richness and abundance. The present paper has attempted to quantify the impact of species alternation (especially for the dominant species) on the function of a zooplankton community through a comparative study using CPV values. From the results generated from the present study, it can be hypothesized that fluctuation of CPV being a suitable indicator for evaluating water pollution along pollution gradient quantifies the niche choice of zooplankton community. In addition, CPV effectively reveals the influence of dominant species alteration on community function. CPV supports the view that the presence of dominant species sustains the 
stability and succession of zooplankton community under changing water environments. The combination of biodiversity indicator based on the distributional patterns and CPV can provide a systematic way to understand the relationships among species, biodiversity, and water pollution. Most importantly, these indicators will provide valuable information for wetlands management and eco-restoration processes.

\section{Acknowledgements}

Authors are thankful to the authority of Vidysagar Unversity, Midnapore (West), West Bengal, India for providing Library and Laboratory facilities. The first author is thankful to the laboratory assistants for the collection of the samples and R.V. Briggs for the analysis of water samples.

\section{References}

[1] Adedeji, O.B., Okerentugba, P.O. and Okonko, I.O. (2012) Use of Molecular, Biochemical and Cellular Biomarkers in Monitoring Environmental and Aquatic Pollution. Nature and Science, 10, 83-104.

[2] Dutta, S.M., Mustafi, S.B., Raha, S. and Chakraborty, S.K. (2014) Assessment of Thermal Stress Adaptation by Monitoring Hsp70 and MnSOD in Freshwater Gastropod, Bellamya bengalensis (Lamark 1882). Environmental Monitoring and Assessment, 186, 8961-8967. http://dx.doi.org/10.1007/s10661-014-4057-2

[3] Lange, C.R. and Lange, S.R. (1997) Biomonitoring. Water Environment Research, 69, 900-915. http://dx.doi.org/10.2175/106143097X135118

[4] Sharma, S. and Sharma, P. (2010) Biomonitoring of Aquatic Ecosystem with Concept and Procedures Particular Reference to Aquatic Macro Invertebrates. Journal of American Science, 6, 1246-1255.

[5] Li, L., Zheng, B.H. and Liu, L.S. (2010) Biomonitoring and Bioindicators Used for River Ecosystems: Definitions, Approaches and Trends. Procedia Environmental Sciences, 2, 1510-1524. http://dx.doi.org/10.1016/j.proenv.2010.10.164

[6] Schuyt, K. and Brander, L. (2004) The Economic Values of the World's Wetlands. Prepared with Support from the Swiss Agency for the Environment, Forests and Landscape (SAEFL). WWF, Gland, 1-32.

[7] Mould, D.J., Frahm, E., Salzmann, Th., Miegel, K. and Acreman, M.C. (2010) Evaluating the Use of Diurnal Groundwater Fluctuations for Estimating Evapotranspiration in Wetland Environments: Case Studies in Southeast England and Northeast German. Ecohydrology, 3, 294-305. http://dx.doi.org/10.1002/eco.108

[8] Wilhm, J.L. (1975) Biological Indicators of Pollution. In: Whitton, B.A., Ed., River Ecology, Blackwell Scientific Publication, Oxford, 375-402.

[9] Mason, C.F. (1996) Biology of Freshwater Pollution. 3rd Edition, Longman, London, 1-356.

[10] Chapman, D. (1996) Water Quality Assessments-A Guide to Use of Biota, Sediments and Water in Environmental Monitoring. 2nd Edition, Published on behalf of UNESCO, WHO and UNEP by E and FN Spon, London, 1-626. http://dx.doi.org/10.4324/NOE0419216001

[11] Zwart, D. and Trivedi, R.C. (1995) Manual on Integrated Water Quality Evaluation. RIVM, Bilthoven. RIVM Report 208023003, Appendix 6, 1-101.

[12] Tiner, R.W. (2002) Wetland Indicators: A Guide to Wetland Identification, Delineation, Classification, and Mapping. Lewis Publishers, CRC Press, Boca Raton, 1-397.

[13] Davies, S.P. and Jackson, S.K. (2006) The Biological Condition Gradient: A Descriptive Model for Interpreting Change in Aquatic Ecosystem. Ecological Applications, 16, 1251-1266. http://dx.doi.org/10.1890/1051-0761(2006)016[1251:tbcgad]2.0.co;2

[14] Pradhan, P. and Chakraborty, S.K. (2008) Ecological Study of Rotifera and Its Application for Biomonitoring Freshwater Riverine Environment. Zoological Research in Human Welfare, Paper-31, 289-306.

[15] Ghosh, S.N. and Desai, V.R. (2006) Environmental Hydrology and Hydraulics: Eco-Technological Practices for Sustainable Development. CRC Press, Taylor and Francis Group, Boca Raton, 1-404.

[16] Horwitz, P., Finlayson, C.M. and Weinstein, P. (2012) Healthy Wetlands, Healthy People: A Review of Wetlands and Human Health Interaction. Ramsar Technical Reports, No. 6, 1-114.

[17] Ghosh, D. (1990) Wastewater-Fed Aquaculture in the Wetland of Calcutta-An Overview. In: Edwards, P. and Pullin, R.S.V., Eds., Wastewater-Fed Aquaculture, Proceedings of the International Seminar on Wastewater Reclamation and Reuse for Aquaculture, Calcutta, 6-9 December 1988, ENSIC, AIT, Bangkok, 49-56.

[18] Mukherjee, S. and Kumar, M.D. (2012) Economic Valuation of a Multiple Use Wetland Water System: A Case Study from India. Water Policy, 14, 80-98. http://dx.doi.org/10.2166/wp.2011.120 
[19] Ajibade, F.O., Adeniran, K.A. and Egbuna, C.K. (2013) Phytoremediation Efficiencies of Water Hyacinth in Removing Heavy Metals in Domestic Sewage (A Case Study of University of Ilorin, Nigeria). The International Journal of Engineering and Science (IJES), 2, 16-27.

[20] APHA (2005) Standard Method for the Examination of Water and Waste Water. 20th Edition, American Public Health Association, Washington DC, 1-541.

[21] Michael, R.G. and Sharma, B.K. (1988) Indian Cladocera (Crustacea: Branchiopoda: Cladocera). Fauna of Indian and Adjacent Countries Series. Zoological Survey of India, Kolkata, 1-262.

[22] Battish, S.K. (1992) Freshwater Zooplankton of India. Oxford and IBH Publishing Co., New Delhi, 1-233.

[23] Reddy, Y.R. (2001) Zooplankton Diversity: Freshwater Planktonic Copepoda with Key to Common Calanoid and Cyclopoid Genera in India. In: Sharma, B.K., Ed., Water Quality Assessment, Biomonitoring and Zooplankton Diversity, Ministry of Environment and Forests, Government of India, New Delhi, 174-189.

[24] Benfield, M.C., Grosjean, P., Culverhouse, P.F., Irigoien, X., Sieracki, M.E., Lopez-Urrutia, A., Dam, H.G., Hu, Q., Davis, C.S., Hansen, A., Pilskaln, C.H., Riseman, E.M., Schultz, H., Utgoff, P.E. and Gorsky, G. (2012) Research on Automated Plankton Identification. Oceanography, 20, 172-187. http://dx.doi.org/10.5670/oceanog.2007.63

[25] Sontakke, G. and Mokashe, S. (2014) Diversity of Zooplankton in Dekhu Reservoir from Aurangabad, Maharashtra. Journal of Applied and Natural Science, 6, 131-133.

[26] Pradhan, P. and Chakraborty, S.K. (2006) Diversity of Zooplanktonic Rotifers of River Shilabati, West Midnapore District, West Bengal, India. Aquaculture, 7, 1-19.

[27] Bhunia, G., Pradhan, P., Chanda, G. and Chakraborty, S.K. (2008) Comparative Studies of Water Quality Parameters and Plankton Production after the Application of Different Fertilizers in Cemented Aquaculture Tank and Natural Water Bodies in Paschim Medinipur, West Bengal. Zoological Research in Human Welfare, Paper-45, 421-432.

[28] Halder, P., Bhunia, G., Pradhan, P., Banerjee, S. and Chakraborty, S.K. (2008) Zooplankton Diversity of Freshwater Wetlands in the Lateritic Tracts of South-West Bengal, India. Zoological Research in Human Welfare, Paper-5, 63-74.

[29] Jiang, J.G. and Shan, Y.F. (2003) Development of Biotic Index Using the Correlation of Protozoan Communities with Chemical Water Quality. Journal of Marine and Freshwater Research, 37, 777-792. http://dx.doi.org/10.1080/00288330.2003.9517208

[30] Jiang, J.G. (2006) Development of a New Biotic Index to Assess Freshwater Pollution. Environmental Pollution, 139, 306-317. http://dx.doi.org/10.1016/j.envpol.2005.05.006

[31] Odum, E.P. (1971) Fundamentals of Ecology. Third Edition, W.B. Saunders Co., Philadelphia, 1-574.

[32] Kumar, A. (2014) Studies on Zooplankton Diversity with Special Reference to Similarity and Dissimilarity Index in Glacial Fed Mountainous Goriganga River of Kumaun Himalaya, Uttarakhand, India. Research Journal of Animal, Veterinary and Fishery Sciences, 2, 22-29.

[33] Shivashankar, P. and Venkataramana G.V. (2013) Zooplankton Diversity and Their Seasonal Variations of Bhadra Reservoir, Karnataka, India. International Research Journal of Environment Science, 2, 87-91.

[34] Sanyal, P., Chakraborty, S.K. and Ghosh, P.B. (2015) Phytoremediation of Sewage-Fed Wetlands of East Kolkata Wetlands, India: A Case Study. International Research Journal of Environment Science, 4, 80-89.

[35] Guo, Q., Ma, K., Yang, L., Cai, Q. and He, K. (2010) A Comparative Study of the Impact of Species Composition on a Freshwater Phytoplankton Community Using Two Contrasting Biotic Indices. Ecological Indicators, 10, $296-302$. http://dx.doi.org/10.1016/j.ecolind.2009.06.002

[36] Shen, Y.F., Tan, Y.Y., Gu, M.R., Feng, W.S. and Wu, J.Z. (1995) Monitoring of River Pollution. China Architecture and Building Press, Beijing, 69-308. 